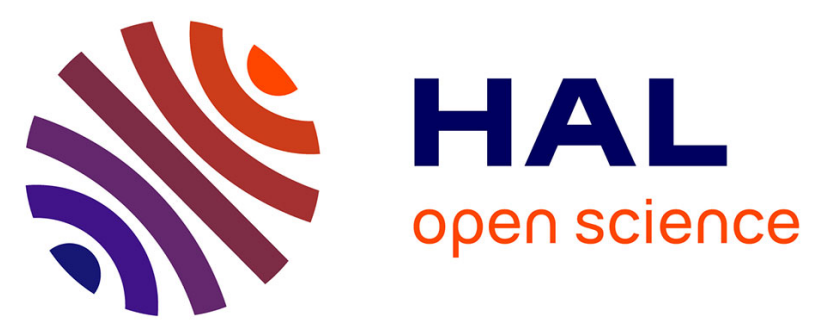

\title{
Paradoxical increase in survival of newborn neurons in the dentate gyrus of mice with constitutive depletion of serotonin.
}

Silvina L. Diaz, Nicolas Narboux-Nême, Sara Trowbridge, Sophie

Scotto-Lomassese, Felix B. Kleine Borgmann, Sebastian Jessberger, Bruno

Giros, Luc Maroteaux, Evan Deneris, Patricia Gaspar

\section{To cite this version:}

Silvina L. Diaz, Nicolas Narboux-Nême, Sara Trowbridge, Sophie Scotto-Lomassese, Felix B. Kleine Borgmann, et al.. Paradoxical increase in survival of newborn neurons in the dentate gyrus of mice with constitutive depletion of serotonin.. European Journal of Neuroscience, 2013, 38 (5), pp.2650-8. 10.1111/ejn.12297 . inserm-00996749

\section{HAL Id: inserm-00996749 https://www.hal.inserm.fr/inserm-00996749}

Submitted on 13 Oct 2017

HAL is a multi-disciplinary open access archive for the deposit and dissemination of scientific research documents, whether they are published or not. The documents may come from teaching and research institutions in France or abroad, or from public or private research centers.
L'archive ouverte pluridisciplinaire HAL, est destinée au dépôt et à la diffusion de documents scientifiques de niveau recherche, publiés ou non, émanant des établissements d'enseignement et de recherche français ou étrangers, des laboratoires publics ou privés. 


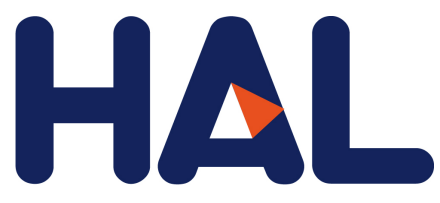

archives-ouvertes

\title{
Paradoxical increase in survival of newborn neurons in the dentate gyrus of mice with constitutive depletion of serotonin.
}

\author{
Silvina Diaz, Nicolas Narboux-Nême, Sara Trowbridge, Sophie \\ Scotto-Lomassese, Felix Kleine Borgmann, Sebastian Jessberger, Bruno Giros, \\ Luc Maroteaux, Evan Deneris, Patricia Gaspar
}

\section{To cite this version:}

Silvina Diaz, Nicolas Narboux-Nême, Sara Trowbridge, Sophie Scotto-Lomassese, Felix Kleine Borgmann, et al.. Paradoxical increase in survival of newborn neurons in the dentate gyrus of mice with constitutive depletion of serotonin.. European Journal of Neuroscience, Wiley, 2013, 38 (5), pp.2650-8. <10.1111/ejn.12297>. <inserm-00996749>

\section{HAL Id: inserm-00996749 http://www.hal.inserm.fr/inserm-00996749}

Submitted on 27 Sep 2017

HAL is a multi-disciplinary open access archive for the deposit and dissemination of scientific research documents, whether they are published or not. The documents may come from teaching and research institutions in France or abroad, or from public or private research centers.
L'archive ouverte pluridisciplinaire HAL, est destinée au dépôt et à la diffusion de documents scientifiques de niveau recherche, publiés ou non, émanant des établissements d'enseignement et de recherche français ou étrangers, des laboratoires publics ou privés. 
Increased survival of newborn neurons in the dentate gyrus of mice with constitutive depletion of serotonin.

Running Title: Serotonin reduction increases DG neuron survival

Silvina Laura Diaz ${ }^{1,2 *}$, Nicolas Narboux-Nême ${ }^{1,2 *}$, Sara Trowbridge ${ }^{1,2}$, Sophie ScottoLomassese $^{1,2}$, Felix Kleine Borgemann ${ }^{3}$, Sebastian Jessberger ${ }^{3}$, Bruno Giros ${ }^{2,4,5}$, Luc Maroteaux $^{1,2}$, Evan Deneris $^{6}$, Patricia Gaspar ${ }^{1,2}$

* equal contribution

1- Inserm, UMR-S 839, Institut du Fer à Moulin, 17, rue du Fer à Moulin, 75005, Paris, France.

2- Université Pierre \& Marie Curie, Paris 75006, France.

3- Institute of Cell Biology, ETH Zurich, Schafmattstrasse 18, 8093 Zurich, Switzerland

4- CNRS UMR 7224, 9 Quai St Bernard, 75005, Paris, France

5- Douglas Hospital, Department of Psychiatry, McGill University, Montreal, Canada

6- Case Western Reserve University, Cleveland, OH 44101 USA.

Corresponding author: Patricia Gaspar, INSERM U839, 17 rue du Fer à Moulin, 75005, Paris, France Tel: 331458761 11; Fax: 331458761 30; email: patricia.gaspar@inserm.fr 


\section{Abstract}

Increased adult neurogenesis is a major neurobiological correlate of the beneficial effects of antidepressants. Indeed, selective serotonin (5-HT) re-uptake inhibitors, which increase 5-HT transmission, enhance adult neurogenesis in the dentate gyrus (DG) of the hippocampus. However, the consequences of 5-HT depletion are still unclear since studies using neurotoxins that target serotonergic neurons, reached contradictory conclusions on the role of 5-HT on DG cells proliferation. Here, we analyzed two genetic models of 5-HT depletion, the Pet $1^{-/}$and the VMAT2 $2^{\text {sert-cre }}$ conditional knockout mice, that have $80 \%$ and $95 \%$ reductions of hippocampal 5-HT, respectively. In both models, we found unchanged cell proliferation of the neural precursors in the DG subgranular zone, whereas a significant increase in the survival of newborn neurons was noted 1 and 4 weeks after BrdU injections. This pro-survival trait was phenocopied pharmacologically with 5-HT synthesis inhibitor PCPA treatment in adults, indicating that this effect was not developmental. Furthermore, one week administration of the $5-\mathrm{HT}_{1 \mathrm{~A}}$ receptor agonist, 8-OH-DPAT, in $\mathrm{Pet}^{-/-}$mice normalized hippocampal cell survival. Overall, our results indicate that constitutive 5-HT depletion does not alter the proliferation of neural precursor in the DG but promotes the survival of newborn cells, an effect which involved activation of the post-synaptic $5-\mathrm{HT}_{1 \mathrm{~A}}$ receptor. The role of 5 -HT in selective neuronal elimination points to a new facet in its multiple effects in controlling neural circuit maturation.

Keywords: genetic mouse models, adult neurogenesis, hippocampus, 5-HT depletion, 5HT1A, 8-OH-DPAT, PCPA 


\section{Introduction}

The production of new neurons in the subgranular zone of the dentate gyrus (DG) of adult mammalian brain is a unique form of structural plasticity which enables hippocampal circuits to adapt to changes in the environment (Koehl and Abrous, 2011). The dentate gyrus subgranular zone continuously generates cells, but a large proportion (70-90\%) of these adult newborn cells is cleared in the first four weeks after their generation (Snyder et al, 2009). Numerous molecular signals and processes have been involved in regulating the neurogenesis and survival of newborn cells and their integration in neural circuits (Fabel and Kempermann, 2008; Kempermann, 2011; Malberg et al, 2000; van Praag et al, 1999; Warner-Schmidt and Duman, 2006). Among these factors, neural activity has been shown to promote cell survival, namely glutamatergic and GABAergic afferents were found to play a role in the modulation of neurogenesis (Toni and Sultan, 2011).

Serotoninergic axons originating from the raphe nuclei innervate the DG (Jacobs et al, 1992) and have also been involved in the control of adult neurogenesis. This is largely based on studies showing that chronic exposure to the selective 5-HT reuptake inhibitors (SSRIs), a widely used class of antidepressants, increased proliferation of neural progenitors (Banasr et al, 2004; Diaz et al, 2012; Malberg et al, 2000; Petrik et al, 2012) and survival of the newborn cells in the DG (Diaz et al, 2012; Encinas et al, 2006; Santarelli et al, 2003). However, the physiological effect of constitutive 5-HT transmission on proliferation and survival remains a matter of debate since pharmacological depletion of 5-HT by the use of the selective 5-HT toxin (5-7 dihydroxytryptamine) led either to a reduction (Brezun and Daszuta, 1999, 2000), or to no change (Huang and Herbert, 2005; Jha et al, 2006) of newborn cell number.

To evaluate the effects of a constitutive 5-HT depletion, we analyzed two genetic models: the

$\mathrm{Pet}^{-/-}$mice, in which a majority of 5-HT neurons in the raphe fail to differentiate (Hendricks 
et al, 2003; Kiyasova et al, 2011), and the VMAT2 ${ }^{\text {sert-cre }}$ mice, which lack vesicular monoamine storage mechanisms in 5-HT neurons (Narboux-Neme et al, 2011). We report that basal proliferation is undisturbed in these two mouse strains, whereas survival of newborn cells is increased. In addition, similar results were obtained using a pharmacological approach for depleting 5-HT in adult WT mice, indicating that this effect is not due to developmental alterations. A normalization of the increased survival phenotype with 5-HT1A agonists in both, Pet $^{-/-}$and pharmacologically 5-HT depleted mice, revealed an unsuspected role of this receptor in controlling the number of surviving newborn cells in the hippocampus. Because it has been recently proposed that the immature DG cells are critical for pattern separation (Nakashiba et al, 2012; Sahay et al, 2011), a form of memory that enables to encode somewhat similar contexts as distinct events, we examined this form of memory in the Pet $^{-/-}$mice. However, no change in memory performance in this test could be observed.

\section{Material and Methods}

\section{Animals}

Procedures involving animals were conducted in accordance with the directives of the European Community (council directive 86/609) and the French Agriculture Ministry (council directive 87-848, 19 October 1987, permissions 00782 to PG).

The Pet $1^{-/-}$mouse line has been described previously (Hendricks et al, 2003). Heterozygote $\mathrm{Pet}^{+/-}$females were mated with Pet $1^{+/-}$or Pet $1^{-/-}$males to produce mixed litters. Both Pet $1^{+/+}$ and $P e t 1^{+/-}$served as controls, since no differences of 5-HT levels or 5-HT innervation between the two genotypes has been reported (Hendricks et al, 2003; Kiyasova et al, 2011) or noted in the present study.

The VMAT2 $2^{\text {sert-cre }}$ mouse line has been described previously (Narboux-Neme et al, 2011). Briefly, these mice result from crossing a floxed VMAT2 mouse line (Bruno Giros, to whom 
correspondence regarding the mouse line should be addressed) to a SERT ${ }^{\text {cre }}$ mouse line (Zhuang et al, 2005). VMAT2 $2^{\text {lox/lox}:: ~ S E R T ~}{ }^{\text {cre/+ }}$ mice were mated with female VMAT2 ${ }^{\text {lox/lox }}$ to generate recombinant and control littermates as previously described (Narboux-Neme et al, 2011).

The two mouse lines were maintained on a C57BL/6J background and littermates were used in all experiments. After weaning, males and females were housed separately ( 5 animals per cage) and maintained under standard laboratory conditions $\left(22 \pm 1^{\circ} \mathrm{C}, 60 \%\right.$ relative humidity, 12-12 hrs light-dark cycle, food and water ad libitum).

Pharmacological studies were performed on wild type (WT) C57BL/6J mice (purchased from Janvier, France).

\section{Proliferation and survival assays.}

Dividing cells were labelled with the thymidine analogue 5-Bromo-2'deoxyuridine (BrdU; Sigma, B9285) as previously described (Diaz et al, 2012). To study cell survival at 4 and 16 weeks, it is necessary to use relatively high doses of BrdU to ensure that it is not diluted in the process of re-division of daughter cells (Wojtowicz and Kee, 2006). Animals received 2 injections of BrdU $150 \mathrm{mg} / \mathrm{kg}$ at $2 \mathrm{hrs}$ interval, a dose that has previously been proved to be non toxic for proliferating and immature neurons (Hancock et al, 2009). BrdU was dissolved in $0.9 \% \mathrm{NaCl}$ at $50^{\circ} \mathrm{C}$, and the $\mathrm{pH}$ was set at 7.4 with $\mathrm{NaOH} 10 \mathrm{M} .7$-week-old VMAT2 ${ }^{\text {sert-cre }}$, Pet $^{-/-}$and their respective controls ( $\mathrm{n}=3-6 /$ experimental group) were sacrificed either $24 \mathrm{hrs}$, 1 week, 4 weeks or 16 weeks after BrdU administration and brains were recovered for cell proliferation and survival studies.

\section{Chronic treatment with PCPA}

To study the effect of chronic 5-HT depletion in adults, 4 week-old WT mice received a daily intraperitoneal (i.p.) injection of PCPA at $300 \mathrm{mg} / \mathrm{kg}$ during the first 3 days, and at $100 \mathrm{mg} / \mathrm{kg}$ for the rest of the treatment (Suppl Fig. 2) (Vitalis et al, 2007). After 4 weeks of PCPA 
treatment, BrdU was administered as described above. A group of mice was sacrificed $24 \mathrm{hrs}$ later for proliferation assays and a second group continued receiving PCPA injections during 1 or 4 extra weeks for survival assays.

\section{8-OH-DPAT treatment}

A group of 4 weeks PCPA-treated and control Pet1 ${ }^{-/-}$mice (7-8 week-old) received 2 injections of BrdU as described above. 24 hrs later, animals received 2 daily i.p. injections of the $5-\mathrm{HT}_{1 \mathrm{~A}}$ agonist 8 -OH-DPAT at $0.5 \mathrm{mg} / \mathrm{kg}$ or vehicle $(\mathrm{NaCl} 0.9 \%)$ during 7 days and sacrificed the day of the last injection.

\section{Retrovirus-mediated labeling of new hippocampal granule cells}

$300 \mathrm{nl}$ of retroviral vector CAG-GFP (Zhao et al, 2006) were injected into the dentate gyrus of $\mathrm{Pet}^{-/-}$and $\mathrm{Pet}^{+/-}$mice at the following coordinates: anteroposterior, -1.7 ; lateral, $-/+1.7$; ventral, -1.75 by using the bregma as reference. Mice were perfused one week later and 100 $\mu \mathrm{m}$ sections were made with a vibratome (VT1000S, Leica).

\section{Histological methods}

Mice were deeply anesthetized (xylazine, $20 \mathrm{mg} / \mathrm{kg}$; pentobarbital, $50 \mathrm{mg} / \mathrm{kg}$ ) and transcardially perfused with $5 \mathrm{ml}$ of $\mathrm{NaCl} 0.9 \%$ and $50 \mathrm{ml}$ of $4 \%$ paraformaldehyde in $0.1 \mathrm{M}$ phosphate-buffered saline (1X PBS, $\mathrm{pH} 7.4$ ) for $15 \mathrm{~min}$. Brains were recovered, postfixed for $24 \mathrm{hrs}$ at $4^{\circ} \mathrm{C}$ and sliced to $50 \mu \mathrm{m}$ thick coronal sections with a vibratome. Sections were stored at $-20^{\circ} \mathrm{C}$ in cryoprotectant $(30 \%$ ethylene glycol, $30 \%$ glycerol in $0.12 \mathrm{M}$ phosphate buffer) if not used immediately.

Newborn cells were revealed by peroxidase immunostaining of BrdU. Free-floating sections were incubated overnight in $0.1 \% \mathrm{H}_{2} \mathrm{O}_{2}$, and exposed to $2 \mathrm{~N} \mathrm{HCl}$ for $1 \mathrm{hr}$. Sections were incubated overnight at $4^{\circ} \mathrm{C}$ with a rat anti-BrdU (1:400; AbDserotec OBT0030; clone BU1/75-ICR1), which was then detected with a biotinylated goat anti-rat antibody during 2 hrs (1:400; Vector). Revelation steps included $1 \mathrm{hr}$ incubation in a streptavidin horseradish 
peroxidase complex (1:400 Amersham) followed by an exposure to 3,3'-diaminobenzidine (DAB) used as substrate.

To identify the type of newborn cells produced in the DG, double-labeling of BrdU and neuronal or astroglial markers were carried out. Rat anti-BrdU (1:400; AbDserotec OBT0030) was combined with a goat anti-doublecortin (1:500; Santa Cruz, immature neuronal marker), an IgM mouse anti-calbindin (1:12000; AbCys: CP331, mature neuronal marker), a rabbit anti-calretinin (1:500; Swant, immature marker) or a rabbit anti-GFAP (1:800; Dako Cytomation, astroglial marker) (overnight, $4^{\circ} \mathrm{C}$ ). Sections were then incubated for $2 \mathrm{hrs}$ at room temperature in the corresponding secondary fluorescent antibodies (1:500; Molecular Probes).

To evaluate morphology of retrovirus-infected new neurons, GFP expression was intensified by permeabilizing $100 \mu \mathrm{m}$-thick sections with proteinase $\mathrm{K}(10 \mu \mathrm{g} / \mathrm{ml} ; 2 \mathrm{~min})$, which was subsequently blocked with $2 \mathrm{mg} / \mathrm{ml}$ glycine. GFP was then detected with a rabbit anti-GFP at $4^{\circ} \mathrm{C}$ overnight (1:5000; Molecular Probes) and revealed at room temperature for $2 \mathrm{hrs}$ with a donkey anti-rabbit (1:500; Molecular probes).

Coronal sections from the hippocampus of WT mice were employed for in situ hybridization as described previously (Narboux-Neme et al, 2008). The following cDNA were used: 5$\mathrm{HT}_{1 \mathrm{~A}}$ (IMAGE:8861702), 5-HT $2 \mathrm{~B}$ (IMAGE:5344328) 5-HT $3 \mathrm{~A}$ (IMAGE:9053347), 5-HT 4 (IMAGE:9053710), 5-HT 6 (IMAGE:40104889), 5-HT 7 (IMAGE:40126305) dig-UTP-labeled probes were used and detected using an antibody coupled to alkaline phosphatase $(1 / 2000$; Roche) and NBT/BCIP was used as blue substrate for in situ revelation.

\section{Analysis and Counting Procedure}

The number of BrdU-labeled cells was quantified with a bright-field microscope with a $40 \mathrm{X}$ objective, on serial sections through the entire hippocampus. One out of 6 sections of the series was counted (300 $\mu \mathrm{m}$ intervals; 6 sections per series). BrdU-labeled cells were counted 
in the subgranular zone (SGZ). Cells were considered to be $\mathrm{BrdU}^{+}$when their nuclei were completely filled with DAB product or showed clear patches of labeling. To facilitate the comparison between the three different mouse models, across different experiments, the number of $\mathrm{BrdU}^{+}$cells was normalized to the control values and expressed as $\%$.

The surface of the DG was measured in 2- and 7-week old VMAT2 ${ }^{\text {sert-cre }}$ and control mice. Briefly, images from Nissl stained- sections through the entire hippocampus (3 mice/experimental condition) were acquired with a $10 \mathrm{X}$ objective and the granular cell layer was outlined using Image $\mathbf{J}$ software.

In proliferation and survival experiments, double-labeled cells (BrdU/ doublecortin calbindin - calretinin - GFAP) in the granular cell layer of the dentate gyrus were imaged with a confocal laser scanning microscope (SP2, Leica, Mannheim, Germany). 45 to $85 \mathrm{BrdU}^{+}$ cells per mouse ( $n=5-6$ mice/experimental group) were analyzed in their entire $z$-axis with a $1-\mu \mathrm{m}$ step to exclude false double-labeling. Double-labeled cells were expressed as percentage of the total $\mathrm{BrdU}^{+}$cells.

In viral-labeling experiments, images were acquired with a $40 \mathrm{X}$ objective, with lateral and zaxis resolutions of 385 and 700nm respectively. Dendritic trees of GFP-expressing new neurons were visualized in 3-D reconstructions using the NeuronStudio software (Rodriguez et al, 2008) to quantify the number of dendritic nodes $(\mathrm{n}=3-4$ mice/experimental group; a total of 193 and $181 \mathrm{GFP}^{+}$cells was analyzed in Pet $1^{-/-}$and Pet $1^{+/-}$mice, respectively).

\section{Pattern separation}

This behavioral test was carried out as previously published (Sahay et al, 2011) using contextual fear-discrimination learning, a type of hippocampal-dependent learning test that captures the animal's ability to discriminate two similar contexts. Briefly, adult (8 to 10 week-

old) $P e t 1^{-/}$male mice were exposed to two similar contexts, with only one of them associated to a foot-shock. The shock-associated training context A, and the similar (no-shock) context 
B, shared many features, such as a stainless steel grid floor and a plastic roof. The differences between contexts were defined in a pilot study. The context B differed from the context $\mathrm{A}$ in that two colored paper inserts were used to cover the lateral walls and a mild limonene scent was used as an olfactory cue. An alcoholic solution was used to clean the grids between runs. The same experimenter manipulated all the animals during all the experiments. Mice were individually brought into the testing room. For discrimination learning, mice were exposed to the training context in which they received a single $2 \mathrm{~s}$ foot shock of $0.8 \mathrm{~mA}$ at $180 \mathrm{~s}$ after placement in the chamber. Mice were taken out of the chamber $15 \mathrm{~s}$ after termination of the foot shock and returned to their home cage. After $1 \mathrm{hr}$, each mouse was placed in the similar B context, in which they were left for $180 \mathrm{~s}$ and were never shocked. On the test-days $1,4,7$, 8 and 10, mice were first exposed to context A before context B, whereas on the test-days 2, 3, 5, 6 and 9, they were first exposed to context B. Measurement of the freezing levels in both the A training context ( 3 min pre-shock) and the similar B context ( $3 \mathrm{~min}$ ) each day allowed the assessment of discrimination between the two contexts and was computed as a discrimination index: (Freezing A context - Freezing $\mathrm{B}$ context) $) /($ Freezing A context + Freezing $\mathrm{B}$ context). A score of 0 indicates complete lack of discrimination (equal freezing levels in both contexts), whereas a score of 1 indicates perfect discrimination (no freezing in context B).

\section{Statistical analysis}

Differences between experimental groups for neurogenic responses were analyzed by the Mann Whitney test. Behavioral studies were analyzed by the One-way ANOVA for repeated measures test. Two-way analysis of variance (ANOVA) was employed in the case of the 8OH-DPAT chronic treatment with genotype and treatment as main factors. Bonferroni's test was used for post hoc comparisons. In all cases, $\mathrm{p}<0.05$ was considered statistically significant. 


\section{Results}

We examined the consequences of constitutive 5-HT depletion on adult DG neurogenesis in two previously characterized genetic mouse models of 5-HT depletion, the $\mathrm{Pet}^{-/-}$and the VMAT2 ${ }^{\text {sert-cre }}$ mice (Hendricks et al, 2003; Narboux-Neme et al, 2011).

In the Pet1 $1^{-/}$, an $80 \%$ depletion of brain 5-HT levels is documented (Hendricks et al, 2003). Basal cell proliferation was assessed in the subgranular zone of the DG in young adults $24 \mathrm{hrs}$ after BrdU injections and we found that the total number of BrdU labeled cells was unchanged in $\operatorname{Pet}^{-/-}$mice $(p=0.69$; Fig 1 a). However when BrdU labeled cells in the DG were counted 4 weeks after the BrdU injections, a significant increase was observed in Pet1 $1^{-/}$ mice as compared to controls ( $\mathrm{p}<0.046$; Fig $1 \mathbf{~ b}$ ), indicating an increase in the survival rate of newborn cells. It is known that 50 to $75 \%$ of the newly produced cells in the DG undergo cell death between the first and fourth week after their generation (Dayer et al, 2003; Snyder et al, 2009). To determine when a difference in survival rate becomes visible in the Pet ${ }^{-/-}$mice, we analyzed newborn cell survival 1 week after BrdU injections and found that Pet1 $^{-/-}$mice already presented an increase of BrdU-labeled cells as compared to control ( $\mathrm{p}<0.029$; Fig 1 c). These results suggest that 5-HT may participate in the new neuron elimination process shortly after their production in the DG, since we calculated that in control mice, $50 \%$ of the newborn cells are lost as early as 1 week after generation confirming that cell death occurs very rapidly after proliferation (Suppl. Fig 1 a).

Given these unexpected results and considering that a few residual 5-HT axons still innervate the subgranular layer of the DG in the Pet1 ${ }^{-/-}$mice (Fernandez and Gaspar, 2012; Kiyasova et al, 2011), we performed the same experiments in another mouse model of 5-HT depletion: the VMAT2 $2^{\text {sert-cre }}$ mice, in which a complete depletion of 5-HT-innervation has been reported (Narboux-Neme et al, 2011). Again, in the proliferation assay, the total number of BrdU labeled cells was unchanged in VMAT2 $2^{\text {sert-cre }}$ mice $(\mathrm{p}=0.96) 24 \mathrm{hrs}$ after BrdU 
injections (Suppl. Fig 2a). In addition, the ratio of $\mathrm{BrdU}^{+}$cells co-expressing the cell cycle marker Ki67 was not different between VMAT2 $2^{\text {sert-cre }}$ and control mice (Suppl. Fig 2e), suggesting that, at least during the first $24 \mathrm{hr}$, the rate of rounds of division is similar in both genotypes. We next evaluated new neuron survival and found that similarly to observations in Pet $^{-/-}$mice, a significant increase in the number of BrdU-labeled cells was observed in $\mathrm{VMAT}^{\text {sert-cre }}$ mice at 4 weeks $(\mathrm{p}=0.0016)$ and 1 week $(\mathrm{p}=0.0152)$ after BrdU injection as compared to controls (Suppl. Fig 2 b - d). The surface of the DG was measured in 2- and 7week old VMAT2 $2^{\text {sert-cre }}$ and no significant difference was detected compared to control mice (Suppl. Fig 2f), suggesting an absolute increase in the number of immature cells in VMAT2 $2^{\text {sert-cre }}$ mice. Altogether, these results indicated that in these two constitutive hyposerotonergic mouse models, relying on different mechanisms of 5-HT depletion, newborn cells are generated in normal numbers but survive in greater numbers.

To determine whether excess of surviving neurons are maintained or eventually cleared later when neural networks become consolidated, we counted BrdU-labeled cells 16 weeks after the initial BrdU injection in VMAT2 ${ }^{\text {sert-cre }}$ mice. This experiment showed a 4-fold increase in new neuron survival $(1335 \pm 501$; vs. control $342 \pm 66, \mathrm{n}=2)$ similar to the one observed after 4 weeks. Altogether these results indicate that constitutive lack of 5-HT neurotransmission results in an increased survival of newborn cells in the DG, with a cumulative effect between 1 and 4 weeks. These supernumerary cells remain integrated in the hippocampal circuits 4 months after their genesis.

Both Pet $^{-/-}$and VMAT2 ${ }^{\text {sert-cre }}$ mice have decreased 5-HT during development that could alter the normal maturation of hippocampal circuits (Trowbridge et al, 2011). Indeed, postnatal growth retardation is observed in hyposerotonergic mouse models (Narboux-Neme et $a l, 2013)$. To determine whether the observed effects on cell survival may result from defects during development, we analyzed mice in which 5-HT depletion was induced in 
adulthood. PCPA (the inhibitor of TPH, the enzyme responsible of 5-HT synthesis) was administered in 7-8 week-old wild type mice during 4 weeks, to induce a pharmacological depletion of 5-HT. By the end of this treatment, BrdU was administered to evaluate both cell proliferation and survival as in the others mouse models (Suppl Fig. 3). The chronic 4 week treatment with PCPA in adult WT mice mimicked the effects previously seen in $\mathrm{Pet}^{-/-}$and VMAT2 ${ }^{\text {sert-cre }}$ mice: no change in cell proliferation $(\mathrm{p}=0.63$; Fig 1 d), but a significant increase in cell survival at 4 weeks $(p<0.02$; Fig 1 e) and at 1 week $(p=0.05$; Fig 1 f) after BrdU administration. These results demonstrated that inducing a 5-HT depletion in adult life is enough to improve survival of the newborn neurons in the DG.

One possible cause of the increased survival rate of the newborn cells in the DG of hyposerotoninergic mouse models could be a change in the maturation rate of newly produced neurons, as demonstrated after SSRI administration (Wang et al, 2008). We analyzed colocalization of BrdU with calretinin and doublecortin, which are markers of immature neurons, and with calbindin, a marker of more mature neurons. Experiments were performed in the Pet $1^{-/}$and control mice, 1 and 2 weeks after BrdU injections. These experiments showed an identical proportion of co-labeled cells in both genotypes (Fig 2a-a', b-b'), indicating that the surplus surviving newborn cells matured normally. The cell fate of the 4 week-old hippocampal newborn neurons was examined by using double labeling of BrdU and the mature neuronal marker NeuN. The proportion of newborn cells that became neurons $(80-$ 90\%) was similar in all genotypes. Finally, we analyzed the morphological maturation of the newborn neurons, using retroviral vectors that integrate only in the dividing cells. Newborn GFP-labeled cells showed a comparable morphological maturation of dendritic trees in Pet $1^{-/-}$ and control mice (Fig 2 c-c').

Immature DG cells have been recently proposed as playing a role in the pattern separation process (Nakashiba et al, 2012; Sahay et al, 2011). To evaluate the functionality of 
these supernumerary immature DG cells found in hyposerotonergic mice, Pet1 ${ }^{-/-}$mice were tested in a contextual fear discrimination learning. In a pilot study, we evaluated the level of freezing in the shock-associated context on day 0 and found negligible levels of freezing for both genotypes ( $p=0.09$; Fig 3 a). Similar increased freezing times were found for both genotypes on day 1, i.e. 24 hrs after the first exposure to the context A ( $p=0.24$; Fig 3 a), suggesting that $P e t 1^{-/-}$and control mice acquired and retained contextual fear conditioning at a similar rate in our experimental conditions. As expected, control mice showed comparable levels of freezing in both contexts during the first 6 days (Fig 3 b), after which, the discrimination index increased progressively, showing their capacity to discriminate between the shock-associated and no-shock contexts. The level of discrimination was unchanged in Pet $1^{-/-}$mice compared to controls $(p=0.60)$, suggesting that the increased number of immature DG cells in the Pet1 $^{-/-}$mice does not modify performance in pattern separation.

The consistency in the increased survival rate of newborn neurons observed in the 3 different chronic hyposerotonergic models analyzed here suggests that a lack of 5-HT during the first weeks after cell generation in the hippocampus hinders the regulatory mechanisms that normally operate to restrict their number before integrating into functional circuits. We hypothesized that 5-HT may act through specific 5-HT receptors to help selected surviving cells and/or to remove surplus neurons. We examined 5-HT receptor expression in the DG using in situ hybridizations with a large panel of 5-HT receptor probes. We found expression of 65 -HT receptors in the DG of the hippocampus: the 5- $\mathrm{HT}_{1 \mathrm{~A}}, 5-\mathrm{HT}_{2 \mathrm{~B}}, 5-\mathrm{HT}_{3 \mathrm{~A}} 5-\mathrm{HT}_{4}, 5-$ $\mathrm{HT}_{6}$, and $5-\mathrm{HT}_{7}$ receptors (Fig 4 a). The 5- $\mathrm{HT}_{1 \mathrm{~B}}$ and the 5- $\mathrm{HT}_{2 \mathrm{~A}-\mathrm{C}}$ receptors were expressed in the hippocampus but not in the DG cells. The 5- $\mathrm{HT}_{5}$ probe did not provide an interpretable signal. Among the 5-HT receptors expressed in the granular cells of the DG, the 5-HT $1 \mathrm{~A}$ receptor matched best the localization of newborn neurons in the subgranular zone, as also suggested in a recently published work (Klempin et al, 2010). To determine whether the lack 
of $5-\mathrm{HT}_{1 \mathrm{~A}}$ receptor stimulation in the $\mathrm{DG}$ of hyposerotonergic mice may be responsible for the enhanced survival phenotype, we evaluated cell survival in both Pet $1^{-/-}$and PCPA-treated mice following a 1-week treatment with the $5-\mathrm{HT}_{1 \mathrm{~A}}$ receptor agonist 8 -OH-DPAT. Since the 5-HT raphe neurons projecting to the hippocampus do not develop in the Pet $1^{-/-}$mice (Kiyasova et al, 2011), the effects of 8-OH-DPAT in these mutants are essentially postsynaptic. As shown above, the number of 1 week-old neurons was significantly higher in Pet $1^{-/}$mice $(p<0.05)$ and in PCPA-treated mice $(p<0.01)$ compared with their respective control groups (Fig 5 a, b). In control mice, a 1-week treatment with 8-OH-DPAT did not change cell survival. However, the number of newborn cells reestablished the control levels after the 1 -week treatment with 8-OH-DPAT in the Pet1 ${ }^{-/-}(\mathrm{p}<0.05)$ and the PCPA-treated mice $(p<0.01)$, suggesting a cell-autonomous regulation of cell survival via the post-synaptic $5-\mathrm{HT}_{1 \mathrm{~A}}$ receptor. Thus, $5-\mathrm{HT}_{1 \mathrm{~A}}$ post-synaptic receptor stimulation can reverse the enhanced survival observed in genetic and pharmacological models of constitutive 5-HT depletion. 


\section{Discussion}

The present observations demonstrate that 5-HT is: (i) dispensable for neural stem cell and progenitor proliferation in the DG and (ii) necessary for the removal of surplus immature newborn neurons via post-synaptic $5-\mathrm{HT}_{1 \mathrm{~A}}$ receptor stimulation.

A number of studies report that enhanced hippocampal neurogenesis is required for the therapeutic response to the increased 5-HT levels induced by SSRIs treatments (Malberg et al, 2000; Santarelli et al, 2003) rev. in Samuels and Hen, 2011 (Samuels and Hen, 2011). Conversely this observation would predict that, reduced neurogenesis should be observed in hyposerotonergic mice, although there is as yet little evidence that impaired neurogenesis has a causal role in the etiology of depression (Pittenger and Duman, 2008)see the meta-analysis in (Petrik et al, 2012)). Initial studies in rats by Daszuta et al. showed a strong reduction in hippocampal cell proliferation after serotonergic 5,7-DHT lesions in the raphe (Brezun et al, 1999, 2000). However, subsequent studies using 5,7-DHT lesions by ICV injections, reported a change neither on cell proliferation (Huang et al, 2005) nor on cell survival (Jha et al, 2006). These conflicting reports suggest that 5-HT could play multiple and perhaps opposing roles, via different 5-HT receptors, in the regulation of the different neurogenic stages. Nevertheless, experimental factors, such as mode of 5-HT depletion/up-regulation, duration of treatment and timing of observations, could probably also account for these discrepancies (Huang et al, 2005; Jha et al, 2006). Here, we found that there was no change in cell proliferation in the DG of three independent models of 5-HT depletion: complete loss of 5HT-storage in the VMAT2 $2^{\text {sert-cre }}$ axons (Narboux-Neme et al, 2011), failure to differentiate raphe neurons in $\mathrm{Pet}^{-/-}$mice (Hendricks et al, 2003; Kiyasova et al, 2011), and pharmacological inhibition of 5-HT synthesis. These results indicate that 5-HT depletion had 
no effect on neural stem cells or progenitor cell cycle as demonstrated in $\mathrm{VMAT}^{\text {sert-cre }}$ mice in which the ratio $\mathrm{BrdU}^{+}-\mathrm{Ki}^{+} 7^{+} / \mathrm{BrdU}^{+}-\mathrm{Ki}^{-} 7^{-}$is similar to that in control mice.

Majority of the cells generated in the DG of WT mice die during the cell differentiation process (Snyder et al, 2009), and it was even recently demonstrated that this cell death occurs between 1 and 4 days after cell birth (Sierra et al, 2010). In our study, we also found in WT animals, that most of the newborn neurons are eliminated within the first week of maturation. By contrast, all our three 5-HT depletion models show a robust increase in newborn neuron survival, an effect that is observed as early as one week after their birth and that seems to last at least for 16 weeks, with no change in the DG surface. Interestingly, the magnitude of increase in the cell survival was inversely correlated with the 5-HT amount: increase in DG cell survival was stronger in VMAT2 $2^{\text {sert-cre }}$ mice that show the most severe 5-HT depletion (Kiyasova et al, 2011; Narboux-Neme et al, 2011), compared to the Pet1 ${ }^{-/-}$mice and PCPA treated mice in which biosynthesis 5-HT level is not totally abolished (Vitalis et al, 2007), These observations indicate that 5-HT is required in the process of eliminating newborn neurons.

Several 5-HT receptors have been implicated in the neurogenic effects of antidepressants (Banasr et al, 2004; Diaz et al, 2012; Klempin et al, 2010; Santarelli et al, 2003; Soumier et al, 2010). Particularly, the downregulation of presynaptic 5-HT $1 \mathrm{~A}$ receptors induced by chronic SSRI treatment has been proposed to be required for the expression of some behavioural effects (Popa et al., 2010). To determine which 5-HT receptors is involved in the effects of 5-HT depletion on neuron survival, we performed an in situ hybridization screen and found that $5-\mathrm{HT}_{1 \mathrm{~A}}$ receptor displays an interesting distribution because it is expressed in the subgranular zone as previously shown (Klempin et al, 2010), where stem cells and progenitor cells are located (Encinas et al, 2006). However, 5- $\mathrm{HT}_{1 \mathrm{~A}}{ }^{-/-}$mice show no change in basal levels of BrdU incorporation (Santarelli et al, 2003) and studies using various 5-HT 
receptor agonists or antagonists have all concluded that $5-\mathrm{HT}_{1 \mathrm{~A}}$ agonist stimulation from one to two weeks had no effect in DG BrdU ${ }^{+}$cell numbers in WT animals (Banasr et al, 2004; Huang et al, 2005; Klempin et al, 2010; Soumier et al, 2010). Indeed, we confirmed that a one-week treatment with 8-OH-DPAT did not alter $\mathrm{BrdU}^{+}$cell number in control mice. In contrast, the same treatment normalized the number of newborn cells to control levels in both $\mathrm{Pet}^{-/-}$mice and PCPA-treated WT mice. The strong reduction of the 5-HT innervation in the hippocampus of $\mathrm{Pet}^{-/-}$mice allows us to conclude that the results obtained herein reflect mostly the involvement of post-synaptic $5-\mathrm{HT}_{1 \mathrm{~A}}$ receptor stimulation in the regulation of cell survival and suggest a role for $5-\mathrm{HT}$, via the $5-\mathrm{HT}_{1 \mathrm{~A}}$ receptor, in the differentiation-or-death decision of newborn cells. Interestingly, the vast majority of DG newborn cells undergoes death by apoptosis in the first 4 days of their life, during the transition from amplifying neural progenitors to early post-proliferative neuroblasts (Sierra et al, 2010). The 5-HT survivalapoptosis decision, 5- $\mathrm{HT}_{1 \mathrm{~A}}$ receptor-dependant, may correspond to this transition from late dividing neural progenitors to early postmitotic neuroblasts.

Increased survival of newborn neurons may be expected to have impacts on memory and learning (rev. in Koehl et al, 2011) and depressive-like phenotypes (rev. in Petrik et al, 2012), although recent reviews underlined the difficulty to establish a causal role of increased neurogenesis for the control of these behaviours. Cytostatic drugs, irradiation, and genetic manipulation demonstrated that the ablation of newborn neurons impairs several forms of hippocampus-depending learning and memory. However, controlled elimination of newborn cells by cell death is also crucial, since mice with disruption of the pro-apoptotic factor Bax performed worse than control mice in spatial memory tests, whereas pattern separation was improved (Dupret et al, 2007; Sahay et al, 2011). Likewise, another genetically modified mouse model with an increased population of young DG cells exhibited enhanced pattern separation between similar contexts (Nakashiba et al, 2012). In contrast, we report here that 
$\mathrm{Pet}^{-/-}$mice have a normal performance in pattern separation, although they have an increased number of immature DG cells. However it is possible that in the hyposerotoninergic mouse lines, the functional deficits caused by globally decreased 5-HT neurotransmission prevents the potential beneficial effect of an increased number of immature neurons in the DG. Moreover, despite the apparently normal maturation of newborn neurons at early stages (1 week) it is possible that late maturation or integration of these neurons in functional circuits is suboptimal in conditions of hyposerotoninergia. It remains to be determined whether the increase in the number of adult born neurons is responsible for some of the behavioral traits observed in the Pet $^{-/-}$mice such as enhanced conditioned fear responses (Kiyasova et al., 2011). Moreover it should be noted that our results are consistent with a possible relationship between enhanced neurogenesis and reduced depression-like behaviour (Pittenger et al, 2008), since VMAT2 ${ }^{\text {sert-cre }}$ mice displayed enhanced struggling in the tail suspension test (Narboux-Neme et al, 2011) while Pet $1^{-/-}$showed no changes floating time in the forced swim test (Diaz et al, 2012), and both lines showed anxiolytic-like response in the noveltysuppressed feeding test (Kiyasova et al., 2011, Narboux-Neme et al, 2011).

The present findings add new insights in the mechanisms and pathways that finely regulate early stages of neurogenesis and pave the way for future studies to better comprehend the factors influencing the fate of immature newborn DG cells. 


\section{Acknowledgments:}

This research was funded by Institut National de la Recherche et de la Santé (Inserm), the Université Pierre et Marie Curie (Paris 6), the European Commission (FP7-health-2007-A201714) and the Agence Nationale pour la recherche (ANR-MNP-neur-032). SD and NN were supported by fellowships from the Région Ile de France, ST was supported by the Henry Russell Shaw travelling fellowship from Harvard University. The laboratory of PG is part of the Ecole des Neurosciences de Paris, training network.

\section{Disclosure:}

The authors have no financial interests or conflict of interest to disclose, 


\section{References}

Banasr M, Hery M, Printemps R, Daszuta A (2004). Serotonin-induced increases in adult cell proliferation and neurogenesis are mediated through different and common 5-HT receptor subtypes in the dentate gyrus and the subventricular zone. Neuropsychopharmacology 29(3): 450-460.

Brezun JM, Daszuta A (1999). Depletion in serotonin decreases neurogenesis in the dentate gyrus and the subventricular zone of adult rats. Neuroscience 89(4): 999-1002.

Brezun JM, Daszuta A (2000). Serotonergic reinnervation reverses lesion-induced decreases in PSA-NCAM labeling and proliferation of hippocampal cells in adult rats. Hippocampus 10(1): 37-46.

Dayer AG, Ford AA, Cleaver KM, Yassaee M, Cameron HA (2003). Short-term and longterm survival of new neurons in the rat dentate gyrus. J Comp Neurol 460(4): 563-572.

Diaz SL, Doly S, Narboux-Neme N, Fernandez S, Mazot P, Banas SM, et al (2012). 5HT(2B) receptors are required for serotonin-selective antidepressant actions. Mol Psychiatry 17(2): 154-163.

Dupret D, Fabre A, Dobrossy MD, Panatier A, Rodriguez JJ, Lamarque S, et al (2007). Spatial learning depends on both the addition and removal of new hippocampal neurons. PLoS Biol 5(8): e214.

Encinas JM, Vaahtokari A, Enikolopov G (2006). Fluoxetine targets early progenitor cells in the adult brain. Proc Natl Acad Sci U S A 103(21): 8233-8238.

Fabel K, Kempermann G (2008). Physical activity and the regulation of neurogenesis in the adult and aging brain. Neuromolecular Med 10(2): 59-66.

Fernandez SP, Gaspar P (2012). Investigating anxiety and depressive-like phenotypes in genetic mouse models of serotonin depletion. Neuropharmacology 62(1): 144-154.

Hancock A, Priester C, Kidder E, Keith JR (2009). Does 5-bromo-2'-deoxyuridine (BrdU) disrupt cell proliferation and neuronal maturation in the adult rat hippocampus in vivo? Behav Brain Res 199(2): 218-221.

Hendricks TJ, Fyodorov DV, Wegman LJ, Lelutiu NB, Pehek EA, Yamamoto B, et al (2003). Pet-1 ETS gene plays a critical role in 5-HT neuron development and is required for normal anxiety-like and aggressive behavior. Neuron 37(2): 233-247.

Huang GJ, Herbert J (2005). The role of 5-HT1A receptors in the proliferation and survival of progenitor cells in the dentate gyrus of the adult hippocampus and their regulation by corticoids. Neuroscience 135(3): 803-813.

Jacobs BL, Azmitia EC (1992) Structure and function of the brain serotonin system. Physiol Rev 72: 165-229. 
Jha S, Rajendran R, Davda J, Vaidya VA (2006). Selective serotonin depletion does not regulate hippocampal neurogenesis in the adult rat brain: differential effects of pchlorophenylalanine and 5,7-dihydroxytryptamine. Brain Res 1075(1): 48-59.

Kempermann G (2011). Seven principles in the regulation of adult neurogenesis. Eur $J$ Neurosci 33(6): 1018-1024.

Kiyasova V, Fernandez SP, Laine J, Stankovski L, Muzerelle A, Doly S, et al (2011). A genetically defined morphologically and functionally unique subset of 5-HT neurons in the mouse raphe nuclei. $J$ Neurosci 31(8): 2756-2768.

Klempin F, Babu H, De Pietri Tonelli D, Alarcon E, Fabel K, Kempermann G (2010). Oppositional effects of serotonin receptors 5-HT1a, 2, and 2c in the regulation of adult hippocampal neurogenesis. Front Mol Neurosci 3.

Koehl M, Abrous DN (2011). A new chapter in the field of memory: adult hippocampal neurogenesis. Eur J Neurosci 33(6): 1101-1114.

Malberg JE, Eisch AJ, Nestler EJ, Duman RS (2000). Chronic antidepressant treatment increases neurogenesis in adult rat hippocampus. $J$ Neurosci 20(24): 9104-9110.

Nakashiba T, Cushman JD, Pelkey KA, Renaudineau S, Buhl DL, McHugh TJ, et al (2012). Young dentate granule cells mediate pattern separation, whereas old granule cells facilitate pattern completion. Cell 149(1): 188-201.

Narboux-Neme N, Angenard G, Mosienko V, Klempin F, Pitychoutis PM, Deneris E, et al (2013). Postnatal growth defects in mice with constitutive depletion of central serotonin. $A C S$ Chem Neurosci 4(1): 171-181.

Narboux-Neme N, Pavone LM, Avallone L, Zhuang X, Gaspar P (2008). Serotonin transporter transgenic (SERTcre) mouse line reveals developmental targets of serotonin specific reuptake inhibitors (SSRIs). Neuropharmacology 55(6): 994-1005.

Narboux-Neme N, Sagne C, Doly S, Diaz SL, Martin CB, Angenard G, et al (2011). Severe serotonin depletion after conditional deletion of the vesicular monoamine transporter 2 gene in serotonin neurons: neural and behavioral consequences. Neuropsychopharmacology 36(12): 2538-2550.

Petrik D, Lagace DC, Eisch AJ (2012). The neurogenesis hypothesis of affective and anxiety disorders: are we mistaking the scaffolding for the building? Neuropharmacology 62(1): 2134.

Pittenger C, Duman RS (2008). Stress, depression, and neuroplasticity: a convergence of mechanisms. Neuropsychopharmacology 33(1): 88-109.

Rodriguez A, Ehlenberger DB, Dickstein DL, Hof PR, Wearne SL (2008). Automated threedimensional detection and shape classification of dendritic spines from fluorescence microscopy images. PLoS One 3(4): e1997. 
Sahay A, Scobie KN, Hill AS, O'Carroll CM, Kheirbek MA, Burghardt NS, et al (2011). Increasing adult hippocampal neurogenesis is sufficient to improve pattern separation. Nature 472(7344): 466-470.

Samuels BA, Hen R (2011). Neurogenesis and affective disorders. Eur J Neurosci 33(6): 1152-1159.

Santarelli L, Saxe M, Gross C, Surget A, Battaglia F, Dulawa S, et al (2003). Requirement of hippocampal neurogenesis for the behavioral effects of antidepressants. Science 301(5634): 805-809.

Sierra A, Encinas JM, Deudero JJ, Chancey JH, Enikolopov G, Overstreet-Wadiche LS, et al (2010). Microglia shape adult hippocampal neurogenesis through apoptosis-coupled phagocytosis. Cell Stem Cell 7(4): 483-495.

Snyder JS, Choe JS, Clifford MA, Jeurling SI, Hurley P, Brown A, et al (2009). Adult-born hippocampal neurons are more numerous, faster maturing, and more involved in behavior in rats than in mice. J Neurosci 29(46): 14484-14495.

Soumier A, Banasr M, Goff LK, Daszuta A (2010). Region- and phase-dependent effects of 5-HT(1A) and 5-HT(2C) receptor activation on adult neurogenesis. Eur Neuropsychopharmacol 20(5): 336-345.

Toni N, Sultan S (2011). Synapse formation on adult-born hippocampal neurons. Eur $J$ Neurosci 33(6): 1062-1068.

Trowbridge S, Narboux-Neme N, Gaspar P (2011). Genetic models of serotonin (5-HT) depletion: what do they tell us about the developmental role of 5-HT? Anat Rec (Hoboken) 294(10): 1615-1623.

van Praag H, Kempermann G, Gage FH (1999). Running increases cell proliferation and neurogenesis in the adult mouse dentate gyrus. Nat Neurosci 2(3): 266-270.

Vitalis T, Cases O, Passemard S, Callebert J, Parnavelas JG (2007). Embryonic depletion of serotonin affects cortical development. Eur J Neurosci 26(2): 331-344.

Wang JW, David DJ, Monckton JE, Battaglia F, Hen R (2008). Chronic fluoxetine stimulates maturation and synaptic plasticity of adult-born hippocampal granule cells. J Neurosci 28(6): $1374-1384$.

Warner-Schmidt JL, Duman RS (2006). Hippocampal neurogenesis: opposing effects of stress and antidepressant treatment. Hippocampus 16(3): 239-249.

Wojtowicz JM, Kee N (2006). BrdU assay for neurogenesis in rodents. Nat Protoc 1(3): 1399-1405.

Zhao ZQ, Scott M, Chiechio S, Wang JS, Renner KJ, Gereau RWt, et al (2006). Lmx1b is required for maintenance of central serotonergic neurons and mice lacking central serotonergic system exhibit normal locomotor activity. J Neurosci 26(49): 12781-12788. 
Zhuang X, Masson J, Gingrich JA, Rayport S, Hen R (2005). Targeted gene expression in dopamine and serotonin neurons of the mouse brain. J Neurosci Methods 143(1): 27-32. 


\section{Figures}

Figure 1. Hippocampal cell proliferation and survival in two hyposerotoninergic mice models.

Cell proliferation in the subgranular zone $24 \mathrm{~h}$ after BrdU administration was similar in (a) control mice and Pet $^{-/-}(n=4)$ or $(\mathbf{d})$ PCPA treated WT mice $(n=3-4)$. On the contrary, cell survival in the cell granular layer, analyzed 4 weeks $(\mathbf{b}, \mathbf{e})$ or 1 week $(\mathbf{c}, \mathbf{f})$ after $\mathrm{BrdU}$ administration, was increased in $(\mathbf{b}, \mathbf{c})$ the $\operatorname{Pet}^{-/-}(n=8-10$, and $n=6-7$, respectively), and in (e, f) the PCPA treated WT mice ( $n=5$, and $n=3$, respectively) compared to their respective controls. $* \mathrm{p}<0.05$ comparing to control groups. Data are expressed as mean + SEM.

\section{Figure 2. Normal differentiation of newborn neurons in Pet1 $^{-/-}$mice.}

(a-b') Multiple immunohistochemistry were performed on control of Pet1 ${ }^{-/-}$mice one week after BrdU injection. The proportion of cells expressing a differentiation marker within BrdU positive cells was measured and compared between genotypes. We checked the expression of the immature neuron markers Calretinin (CalR a, a') and Doublecortin (Dcx, b, b'), as well as the expression of the marker of mature DG neurons Calbindin (Cabp, a, a'). No difference was found in the expression of these markers between genotypes. (c-c') Analysis of the morphology of newborn neurons was performed one week after the injection of GFPexpressing retrovirus. The number of nodes was quantified for each labeled cell as a marker of differentiation. No significant difference was found between controls and Pet1 ${ }^{-/-}$mice. Scale bar $=20 \mu \mathrm{m}$

Figure 3. Increased number of immature cells does not enhance contextual discrimination in Pet1 ${ }^{-/-}$mice. 
(a) On day $0, \mathrm{Pet}^{-/-}$and control mice showed negligible levels of freezing in context A before receiving the foot shock $(n=4-6)$. On day 1 , both groups showed comparable levels of conditioning to training context $\mathrm{A}(\mathrm{n}=11-13)$. (b) Freezing levels as indicated by the discrimination ratio, i.e. (Freezing $\mathrm{A}$ context - Freezing $\mathrm{B}$ context $) /($ Freezing A context + Freezing $\mathrm{B}$ context) were similar in Pet $^{-/-}$and control mice $(n=6-13)$. Data are expressed as mean + SEM.

\section{Figure 4. 5-HT receptor expression in the adult dentate gyrus.}

Representative 5- $\mathrm{HT}_{1 \mathrm{~A}}, 5-\mathrm{HT}_{2 \mathrm{~B}}, 5-\mathrm{HT}_{3 \mathrm{~A}}, 5-\mathrm{HT}_{4}, 5-\mathrm{HT}_{6}$, and 5- $\mathrm{HT}_{7}$ mRNA labeling in the DG of WT mice determined by in situ hybridization . Scale bar $=100 \mu \mathrm{m}$

Figure 5. 5-HT $1 \mathrm{~A}$ agonist administration normalizes cell survival in the DG of hyposerotonergic mice.

After a 1 week-treatment, $8-\mathrm{OH}-\mathrm{DPAT}(0.5 \mathrm{mg} / \mathrm{kg}$; twice a day $)$ did not affect cell survival in control mice, but hindered the increased basal cell survival phenotype described in PET1 ${ }^{-/-}$ mice (a) as well as in 4-week-treated PCPA WT mice (b). Data are expressed as mean + SEM $\left({ }^{*}{ }^{+} \mathrm{p}<0.05 ; * *{ }^{++} \mathrm{p}<0.01 ; \mathrm{n}=3-4\right)$.

\section{Supplementary Figure 1.}

The comparison of the number of $\mathrm{BrdU}^{+}$cells in WT mice $24 \mathrm{~h}$ and 1 week after $\mathrm{BrdU}$ injection indicates that $50 \%$ of the cells labeled one day after BrdU injection are missing one week later. Data are expressed as mean $+\operatorname{SEM}(* * * \mathrm{p}<0.001 ; \mathrm{n}=4-5$ mice for each group).

\section{Supplementary Figure 2.}

(a) Cell proliferation in the subgranular zone $24 \mathrm{~h}$ after BrdU administration was similar in control mice and VMAT2 ${ }^{\text {sert-cre }}(n=7-8)$. On the contrary, cell survival in the cell granular 
layer, analyzed (b) 4 weeks $(n=5-8)$ or $(\mathbf{c}) 1$ week $(n=6)$ after BrdU administration, was increased in the VMAT2 $2^{\text {sert-cre }}$ mice compared to their respective controls. ${ }^{* *} \mathrm{p}<0.01$; $\mathrm{p}$ $<0.05$ comparing to control groups. Data are expressed as mean + SEM. (d) Images correspond to representative BrdU immunolabeling in the DG of VMAT ${ }^{\text {sert-cre }} 4$ weeks after BrdU administration. (e) Proportion of $\mathrm{BrdU}^{+}$cells co-expressing the cell cycle marker Ki67 (green bars) or only $\mathrm{BrdU}^{+}$(red bars) is similar in VMAT2 ${ }^{\text {sert-cre }}$ mice and control mice. (f) The surface of the DG measured in 7-week old VMAT2 $2^{\text {sert-cre }}$ mice was similar in both groups $(\mathrm{n}=5)$. Scale bar $=20 \mu \mathrm{m}$

Supplementary Figure 3. Experimental protocol employed for 5-HT depletion during adulthood. PCPA was administered daily during 4 weeks $(300 \mathrm{mg} / \mathrm{kg}$ for the first 3 days; 100 $\mathrm{mg} / \mathrm{kg}$ for the rest of the treatment) to WT animals. BrdU (2 injections at $150 \mathrm{mg} / \mathrm{kg}$ injected $2 \mathrm{hr}$ apart) was administered i.p. after the first 4 weeks of PCPA treatment. A group of animals was sacrificed $24 \mathrm{hr}$ after BrdU treatment for evaluating cell proliferation whereas another group went on receiving PCPA $100 \mathrm{mg} / \mathrm{kg}$ and sacrificed 1 week or 4 weeks after BrdU treatment for evaluating cell survival. 
a

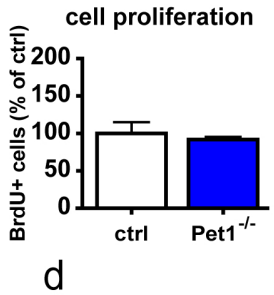

cell proliferation

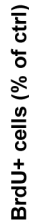

b

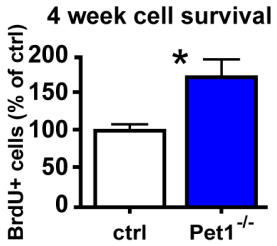

e

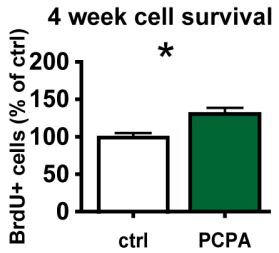

C
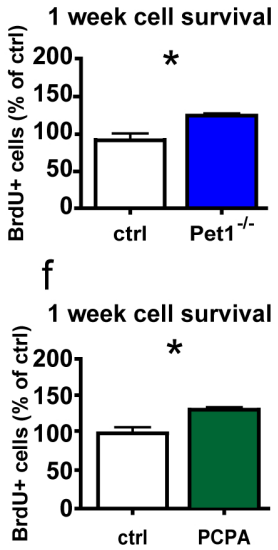

Figure 1 
a
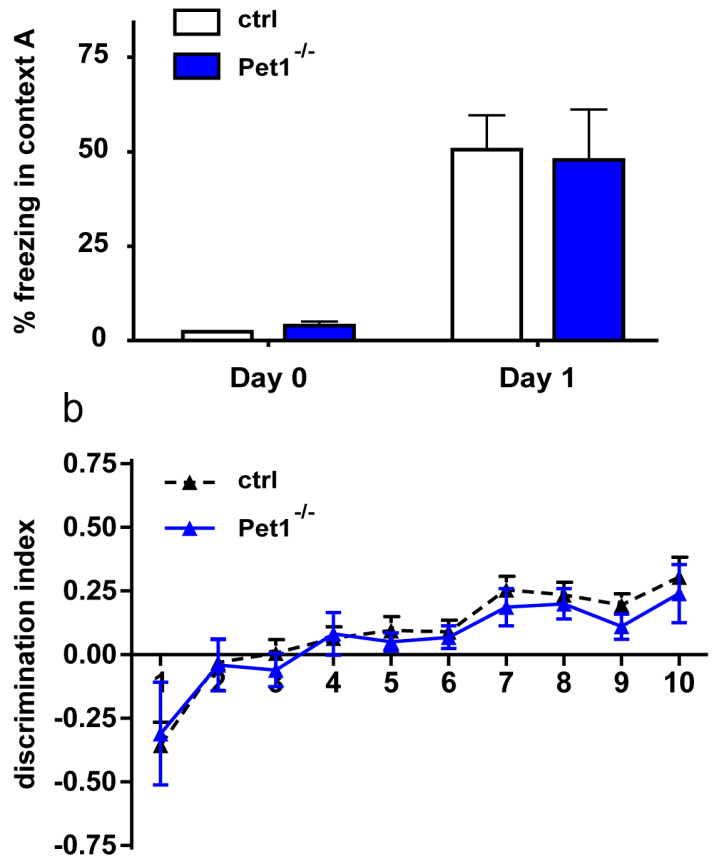

Figure 3 


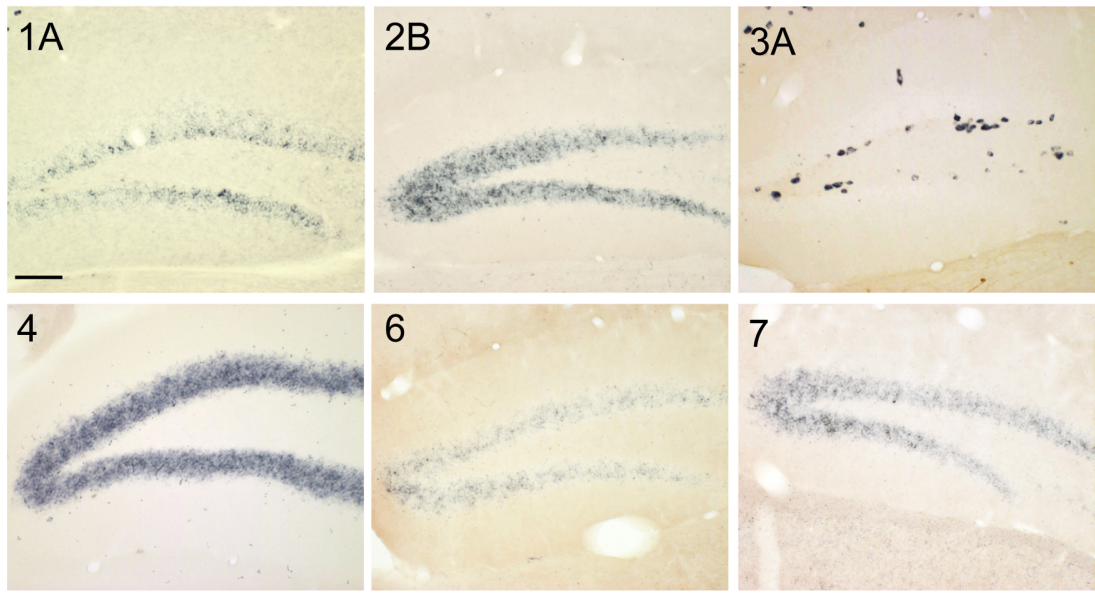

Figure 4 
a

1 week cell survival

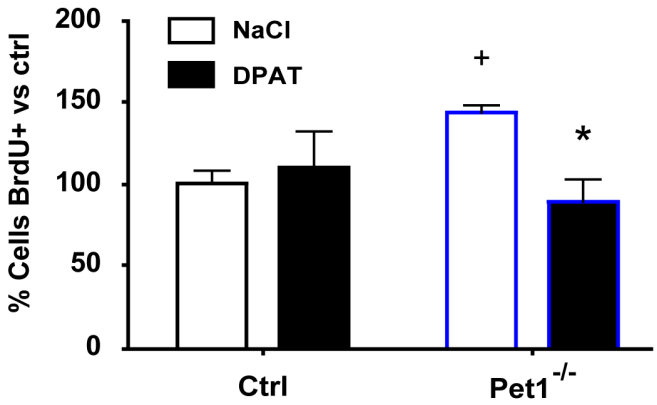

b

1 week cell survival

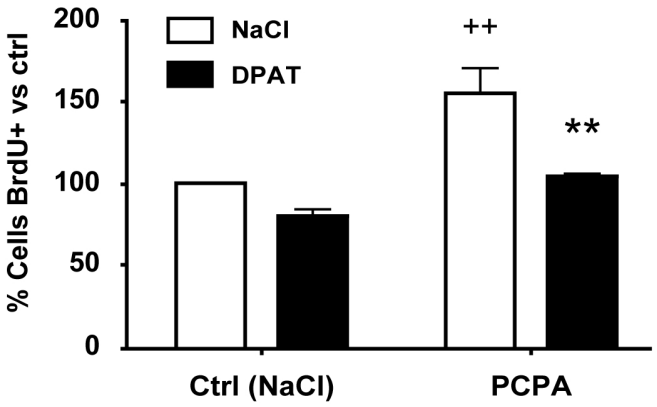

Figure 5 